\title{
Plerixafor prescription modalities in autologous haematopoietic stem cell mobilization in Belgium
}

\author{
D. Selleslag ${ }^{1}$, C. Lambert ${ }^{2}$, P. Zachee ${ }^{3}$, P. Huyngh ${ }^{4}$, A. Van de Velde ${ }^{5}$, L. Noens ${ }^{6}$, \\ L. Baily ${ }^{7}$, M. André ${ }^{8}$, E. Willems ${ }^{9}$, D. Dierickx ${ }^{10}$
}

${ }^{1}$ AZ Sint-Jan Brugge-Oostende, Afdeling Hematologie, Brugge, Belgium, ${ }^{2}$ Cliniques Universitaires Saint-Luc, Service d'hématologie, Bruxelles, Belgium, ${ }^{3} Z$ iekenhuis Netwerk Antwerpen Stuivenberg, Afdeling Hematologie, Antwerpen, Belgium, ${ }^{4}$ Institut Jules Bordet, Service d'Hématologie Clinique et Laboratoire d'Hématologie Waterloolaan 121, Brussel, Belgium, ${ }^{5}$ Universitair Ziekenhuis Antwerpen, Hematologie en Hemostase, Edegem, Belgium, ${ }^{6}$ Universitair Ziekenhuis Gent, Hematologie, Gent, Belgium, ${ }^{7}$ Hôpital Erasme, Service d'hématologie, Bruxelles, Belgium, ${ }^{8} \mathrm{CHU}$ Mont Godinne, Yvoir, Belgium, ${ }^{9}$ Centre Hospitalier Universitaire de Liège, Service d'hématologie, Domaine Universitaire du Sart Tilman, Liège, Belgium, ${ }^{10}$ Universitaire Ziekenhuizen Leuven, Afdeling Hematologie, Leuven, Belgium

Objectives: The efficacy and safety of plerixafor, an antagonist of the CXCR4 receptor, in combination with G-CSF has been demonstrated in patients suffering from lymphoma and multiple myeloma (MM) eligible for autologous haematopoietic stem cell collection. However, different reimbursement criteria have been applied in different countries to select patients eligible for treatment with plerixafor. The objective of this observational study was to describe the plerixafor prescription modalities in daily practice in Belgium.

Methods: This open-label, prospective, observational study was conducted in 11 Belgian centres in 114 patients with lymphoma (Hodgkin's and non-Hodgkin's lymphoma) or MM who were treated with plerixafor according to the SmPC between April 2011 and October 2012. Patients included in another clinical trial with plerixafor were excluded from the study.

Results: The use of plerixafor in patients with MM or lymphoma was effective, with a success rate (defined as a total yield $>2 \times 10^{6} \mathrm{CD} 34+$ cells $/ \mathrm{kg}$ ) of $77 \%$, and well tolerated (one SAE reported). Optimal collection (defined as a total yield $>4 \times 10^{6} \mathrm{CD} 34+$ cells $/ \mathrm{kg}$ ) was obtained for $43 \%$ of the study population ( $31 \%$ in lymphoma patients, compared to $61 \%$ in patients with MM). The use of plerixafor was in line with the SmPC and the Belgian reimbursement criteria for all patients.

Conclusion: This study is showing that the use of plerixafor according to Belgian reimbursement criteria results in similar efficacy and safety as in other centres and countries worldwide.

Keywords: Poor mobilizers, Plerixafor, Non-Hodgkin's lymphoma, Multiple myeloma, Hodgkin's lymphoma

\section{Introduction}

Intensive chemotherapy followed by autologous stem cell transplantation is an important treatment modality for patients suffering from lymphoma or multiple myeloma (MM). ${ }^{1-3}$ This strategy is associated with improved overall survival, event-free and progressionfree survival. ${ }^{4,5}$ Transplantation of autologous haematopoietic stem cells (HSC) is required for the recovery from bone marrow aplasia caused by high dose chemotherapy. ${ }^{6-8}$ However, autologous transplantation can only be performed if an adequate

Correspondence to: Dominik Selleslag, MD, AZ Sint-Jan BruggeOostende, Afdeling Hematologie, Ruddershove 10, 8000 Brugge, Belgium. Email: Dominik.Selleslag@azbrugge.be autologous graft is available. Transplantation with stem cells from peripheral blood has largely replaced transplantation with bone marrow stem cells.

Stem cells can be mobilized to the peripheral blood by the use of a haematopoietic growth factor such as Granulocyte Colony Stimulating Factor (G-CSF). G-CSF can be used with or without mobilizing chemotherapy. However, these mobilization strategies are not always satisfactory. According to recent literature data, the proportion of patients for whom the collection of an adequate graft fails varies from 4 to $48 \%{ }^{1-11}$ In these papers, an adequate graft was defined as a graft containing more than $2 \times 10^{6} \mathrm{CD} 34$ cells per $\mathrm{kg}$ body weight collected in a maximum of 4 to 5 leucapheresis procedures. The failure rate is 
higher in elderly patients, in patients previously treated with myelosuppressive chemotherapy,${ }^{10,12}$ in case of marrow involvement at diagnosis ${ }^{4}$ and especially after failure of a previous mobilization attempt. With the current strategies of mobilization and remobilization, the risk of remobilization failure is much higher than for the first attempt: only $30 \%$ of remobilized patients can undergo autologous stem cell transplantation (HSCT) with the total number of cells obtained during the first and second attempt. ${ }^{8}$

Plerixafor, the active substance of Mozobil ${ }^{\circledR}$, is a bicyclam derivative and is a selective, competitive and reversible antagonist of the CXCR4 receptor expressed on HSC. Plerixafor inhibits the binding of the CXCR4 receptor to its SDF1alpha ligand, produced by stromal cells. By disrupting the CXCR4/SDF1alpha axis plerixafor mobilizes HSC to the peripheral blood, where they can be collected by apheresis. ${ }^{13}$ Plerixafor in combination with GCSF is approved to improve mobilization of HSC to the peripheral blood for collection and subsequent autologous transplantation in patients with lymphoma and MM whose cells mobilize poorly.

The efficacy and safety of plerixafor in combination with G-CSF has been demonstrated in patients suffering from Non-Hodgkin's Lymphoma (NHL) and MM eligible for autologous HSCT. Plerixafor significantly increases the number of $\mathrm{CD} 34+$ cells collected, reduces the number of apheresis procedures required to collect an adequate number of stem cells, increases the chance to collect an optimal graft and reduces the collection failure rate. A significantly higher number of patients are able to proceed to autologous HSCT with plerixafor compared with standard mobilization with G-CSF. ${ }^{13,14}$ In addition, plerixafor overcomes mobilization failures in about $70 \%$ of patients who had already failed a previous collection or mobilization attempt. ${ }^{15-18}$

Worldwide, different criteria are applied to select patients for treatment with plerixafor. In some countries, the use of plerixafor is restricted to patients who need remobilization, while in other countries the use is less restricted. In Europe, the use of plerixafor is mainly restricted to known poor mobilizers. In Belgium, the current reimbursement criteria are as follows: patients with lymphoma or $\mathrm{MM}$ who are candidates for an autologous HSCT and who are failing mobilization (less than $10-15$ cells CD34+ cells/ $\mu$ l blood mobilized) or who are failing collection (less than $2 \times 10^{6} \mathrm{CD} 34+$ cells $/ \mathrm{kg}$ collected) after GCSF administration $(10 \mu \mathrm{g} / \mathrm{kg})$ during at least 4 days or after chemomobilization with G-CSF. The objective of this observational study was to describe the plerixafor prescription modalities in daily practice in Belgium.

\section{Materials and Methods}

This open-label, prospective, multi-centre, observational study was conducted in Belgium in patients treated with plerixafor between April 2011 and October 2012. The study was approved by the Ethics Committee of the University Hospital of Leuven (no. B322201110611) and was performed in compliance with GCP and all local applicable rules and regulations. The study was conducted in 11 Belgian centres. All patients treated with plerixafor who gave their written informed consent and for whom data were available were included in the study. Patients who were already included in another clinical trial with plerixafor were excluded from the study. The following information was recorded: demographics, current and past treatment, previous stem cell mobilization attempts, current mobilization treatment, results of mobilization, and safety. Data were statistically analyzed in a descriptive manner (mean, standard deviation and range).

\section{Results}

\section{Demographics}

In total, 114 patients who were treated with plerixafor according to the SmPC between April 2011 and October 2012 were included in the study (Table 1). This corresponded to $77 \%$ of the total number of Belgian patients treated with plerixafor in the time frame of the study. Of the 114 patients, 46 (40.4\%) were treated for MM, while 68 (59.6\%) patients were treated for lymphoma [59 (51.8\%) patients with NHL and $9(7.9 \%)$ with HL].

All patients with lymphoma (HL + NHL) were previously treated with chemotherapy, compared with 42 MM-patients (91\%). Only $13 \%$ of the total

Table 1 Demographic information for patients with myeloma, lymphoma and the entire study population

\begin{tabular}{|c|c|c|c|}
\hline & $\mathrm{MM}(n=46)$ & $\mathrm{NHL}+\mathrm{HL}(n=68)$ & Total $(n=114)$ \\
\hline Gender (M/F) Number (\%) & $21 / 25(46 \% / 54 \%)$ & $36 / 32(53 \% / 47 \%)$ & $57 / 57(50 \% / 50 \%)$ \\
\hline Mean age $\pm S D$ (range) & $62.5 \pm 7.7$ & $56.1 \pm 15.0$ & $58.7 \pm 12.9$ \\
\hline (in years) & $(42.9-74.7)$ & $(17.6-77.0)$ & $(17.6-77.0)$ \\
\hline Mean height $\pm S D$ (range) & $165.6 \pm 27.7$ & $166.6 \pm 32.4$ & $166.2 \pm 30.6$ \\
\hline (in $\mathrm{cm}$ ) & $(157-193)$ & $(152-196)$ & $(152-196)$ \\
\hline Mean weight $\pm S D$ (range) & $72.5 \pm 16.3$ & $76.9 \pm 16.7$ & $75.1 \pm 16.6$ \\
\hline (in $\mathrm{kg}$ ) & $(45-119)$ & $(47-127.7)$ & $(45-127.7)$ \\
\hline
\end{tabular}

Note: MM, multiple myeloma; NHL, Non-Hodgkin's lymphoma; HL, Hodgkin's lymphoma. 
Table 2 Mobilization history for patients with myeloma, lymphoma and the entire study population

\begin{tabular}{lccc}
\hline & MM $(\boldsymbol{n}=\mathbf{4 6 )}$ & NHL + HL $(\boldsymbol{n}=\mathbf{6 8})$ & Total $(\boldsymbol{n}=\mathbf{1 1 4})$ \\
\hline No previous mobilization & $36(78.3 \%)$ & $47(69.1 \%)$ & $83(72.8 \%)$ \\
Previous mobilization with & $10(21.7 \%)$ & $21(30.8 \%)$ & $31(27.2 \%)$ \\
G-CSF & $4(8.7 \%)$ & $3(4.4 \%)$ & $7(6.1 \%)$ \\
G-CSF+ mobilization chemotherapy & $1(2.2 \%)$ & $3(4.4 \%)$ & $4(3.5 \%)$ \\
G-CSF+therapeutic chemotherapy & $3(6.5 \%)$ & $7(10.3 \%)$ & $10(8.8 \%)$ \\
Other* & $2(2.9 \%)$ & $8(11.8 \%)$ & $10(8.8 \%)$ \\
\hline
\end{tabular}

Note: MM, multiple myeloma; NHL, non-Hodgkin's lymphoma; HL, Hodgkin's lymphoma.

*These 10 patients underwent a previous mobilization session with plerixafor and have been included in this study.

population previously received radiotherapy. More patients with $\mathrm{MM}(n=4 ; 9 \%)$ had received a prior stem cell transplant than patients with lymphoma $(n=1 ; 4.4 \%)$.

\section{Mobilization history in remobilization patients}

In the total population, only $27 \%$ of the patients $(n=31)$ were remobilized patients (Table 2). Previous mobilization was mainly done in steady state using G-CSF alone $(n=7 ; 6.1 \%)$ or on the backbone of therapeutic chemotherapy $(n=10 ; 8.8 \%)$. Specific chemotherapy for mobilization purposes was the least frequently used mobilization regimen $(n=4$; $3.5 \%)$. Ten patients $(8.8 \%)$ had been mobilized with plerixafor in first line and had failed. They were included in this registry as remobilization patients. Of the 31 remobilized patients, $24(77.5 \%)$ underwent one previous mobilization attempt, while five $(16 \%)$ had two attempts and two (6.4\%) had more than two previous mobilization attempts.

In nine of 31 patients, no apheresis had been performed due to low peripheral blood CD34 counts. In 21 of 31 patients, apheresis was performed with an average yield of $\mathrm{CD} 34+$ cells of $3.22 \times 10^{6}$ cells $/ \mathrm{kg}$; seven of these 21 patients had an apheresis yield higher than $2 \times 10^{6}$ cells $/ \mathrm{kg}$. However, these seven patients were considered as poor mobilizers and mobilized with plerixafor in the second round of apheresis due to low pre-apheresis CD34 counts $(<15$ cells $/ \mu \mathrm{l})$ after at least 4 days of G-CSF or due to insufficient yield for double transplant in the first apheresis.

\section{Current mobilization procedure for all patients}

Specific chemotherapy for mobilization purposes only was administered in $13.2 \%$ of all patients $(n=15)$, with the most frequent use in patients with MM (Table 3). Overall, $47.8 \%$ of the MM patients $(n=22)$ were mobilized with G-CSF and plerixafor alone, potentially avoiding the side effects of chemomobilization. In lymphoma patients, mobilization with G-CSF and plerixafor was more frequent $(n=37$; $54.4 \%$ ) than mobilization with G-CSF/plerixafor and chemotherapy. Most cases of chemomobilization in lymphoma were performed in the frame of the chemotherapeutic treatment of the disease. For the 31 patients who already underwent a previous mobilization attempt, the most frequently used mobilization regimen applied the second time was G-CSF in combination with plerixafor $(n=18 ; 58.1 \%)$ (Table 4).

Ninety-six patients $(84.2 \%)$ received one or two administrations of plerixafor in the mobilization regimen (Table 5). Only one patient was treated up to 4 days with plerixafor. For most patients $(n=101$; $88.6 \%$ ), plerixafor was administered in a hospital setting (hospitalization or day care unit).

\section{Mobilization efficacy}

Before mobilization with plerixafor, the mean CD34+ cell count was $10.1 \pm 16.4$ cells $/ \mu 1$. The CD34+ cell count increased 2.78-fold after a first administration of plerixafor $(28.2 \pm 25.1$ cells $/ \mu \mathrm{l})$. For 92 patients $(80.7 \%)$, the pre-apheresis CD34+ cell count before plerixafor was lower than 15 cells/ $\mu$ l. Another seven patients $(6.1 \%)$ were known as poor mobilizers with a collection yield in previous mobilization $\left(<2 \times 10^{6}\right.$ cells $\left./ \mathrm{kg}\right)$ or did not undergo apheresis. For 15 patients $(13 \% ; 10$ patients in the MM-group and 5 patients in the lymphoma-group), the pre-apheresis $\mathrm{CD} 34+$ cell count before plerixafor was higher than 15 cells $/ \mu 1$. However, in 11 of them, one or two apheresis sessions with a collection yield below $2 \times 10^{6}$ cells $/ \mathrm{kg}$ were performed after which the mobilization session was rescued by administration of plerixafor. Two patients with a high pre-apheresis CD34+ cell count were

Table 3 Mobilization regimen used in combination with plerixafor for the total population, divided per myeloma and lymphoma group

\begin{tabular}{lrrr}
\hline & MM $(\boldsymbol{n}=\mathbf{4 6 )}$ & NHL + HL $(\boldsymbol{n}=\mathbf{6 8})$ & Total $(\boldsymbol{n}=\mathbf{1 1 4})$ \\
\hline G-CSF & $22(47.8 \%)$ & $37(54.4 \%)$ & $59(51.7 \%)$ \\
G-CSF+mobilization chemotherapy & $9(19.6 \%)$ & $6(8.8 \%)$ & $15(13.2 \%)$ \\
G-CSF + therapeutic chemotherapy & $15(32.6 \%)$ & $25(36.7 \%)$ & $40(35.1 \%)$ \\
\hline
\end{tabular}

Note: MM, multiple myeloma; NHL, non-Hodgkin's lymphoma; HL, Hodgkin's lymphoma. 
Table 4 Mobilization regimen used in combination with plerixafor for the remobilization patients, divided per myeloma and lymphoma group

\begin{tabular}{lclc}
\hline & MM $(\boldsymbol{n}=\mathbf{2 1})$ & NHL + HL $(\boldsymbol{n}=\mathbf{1 0})$ & Total $(\boldsymbol{n}=\mathbf{3 1})$ \\
\hline G-CSF & $13(62.0 \%)$ & $5(50.0 \%)$ & $18(58.1 \%)$ \\
G-CSF+ mobilization chemotherapy & $0(0.0 \%)$ & $1(10.0 \%)$ & $1(3.2 \%)$ \\
G-CSF+therapeutic chemotherapy & $8(38.0 \%)$ & $4(40.0 \%)$ & $12(38.7 \%)$ \\
\hline
\end{tabular}

Note: MM, multiple myeloma; NHL, non-Hodgkin's Iymphoma; HL, Hodgkin's Iymphoma.

already mobilized with plerixafor a few weeks earlier and were considered as known poor mobilizers. Therefore, the use of plerixafor in these patients with CD34+ cell count exceeding 15 cells/ $\mu$ was also in line with the reimbursement criteria.

On average, $1.79 \pm 0.88$ apheresis days were performed in the total study population. This was slightly lower in the lymphoma-group (1.73 \pm 0.90 ; range: $0-4$ days) compared with the MM-group (1.87 \pm 0.85 ; range: $0-3$ days)

On day 1 of plerixafor administration, 95 patients $(83.3 \%)$ went to apheresis and more than or equal to $2 \times 10^{6}$ cells $/ \mathrm{kg}$ (mean apheresis yield $3.25 \times 10^{6}$ cells $/ \mathrm{kg}$ ) could be collected in $60 \%$ of them. In the total population, the mean total CD34 + cells collected was $4.28 \pm 3.32 \times 10^{6}$ cells $/ \mathrm{kg}$. Collection yields were higher in the MM-group $\left(5.58 \pm 3.64 \times 10^{6}\right.$ cells $\left./ \mathrm{kg}\right)$ in comparison with the lymphoma-group $\left(3.39 \pm 2.76 \times 10^{6}\right.$ cells/ $\mathrm{kg}$ ). In the total study population, success rate (defined as total yield $\geq 2 \times 10^{6} \mathrm{CD} 34+$ cells $/ \mathrm{kg}$ ) was $77 \%$. In first attempt mobilization, this success rate was $82 \%$, while it was $63 \%$ in the group of patients who have been mobilized at least once. Overall success rate and first mobilization success rate was higher in patients with MM than in patients with lymphoma ( 84 vs $72 \%$, and 88 vs $76 \%$, respectively).

The 10 patients who were mobilized with plerixafor in the first and second mobilization attempt were separately analyzed. In all but one of these 10 patients, the apheresis yield of the first mobilization with plerixafor was $<2 \times 10^{6} \mathrm{CD} 34$ cells $/ \mathrm{kg}$.

However, in all but one of the 10 patients a collection of $\geq 2 \times 10^{6} \mathrm{CD} 34 / \mathrm{kg}$ was possible in the second mobilization round with plerixafor, demonstrating that plerixafor can be used successfully in patients that failed a first mobilization round with plerixafor.

The relationship between total yield collection and the pre-plerixafor CD34+ cell count is shown in Table 6 . In the group with a pre-plerixafor pre-apheresis CD34+ cell count less than 5 and more than 2 cells $/ \mu 1$, the success rate, defined as collection yield above $2 \times 10^{6} \mathrm{CD} 34+$ cells $/ \mathrm{kg}$, was $75.8 \%$. For patients with a pre-plerixafor pre-apheresis CD34 + cell count higher than 10 cells/ $\mu 1$, success rate with plerixafor was $100 \%$. Analysis of the relationship between pre-plerixafor CD34+cell counts and the total yield collected per patient shows a relatively high success rate $(40 \%)$ in those patients with very low pre-plerixafor CD34 + cell counts (below 2 cells/ $\mu$ l). Optimal collection, defined as a total collection yield of $4 \times 10^{6}$ cells $/ \mathrm{kg}$, was obtained for $43 \%$ of the total study population $(n=49)(31 \%$ in patients with lymphoma, compared with $61 \%$ in patients with MM).

\section{Safety}

A total of 14 adverse events (AEs) were reported by seven patients $(6.1 \%)$. One patient showed an allergic reaction (including rash, facial oedema and hypotension), which was classified as a serious adverse event (moderate grade). Most frequent adverse events were gastro-intestinal (diarrhoea, nausea and abdominal pain). Hypotension was reported in two additional patients $(1.7 \%)$. Plerixafor was discontinued in three patients and medication was needed in three patients to treat the adverse event (allergic reaction and low blood pressure). All reported events resolved within 24 hours.

\section{Discussion}

The population in this observational study is representative of all patients treated with plerixafor in Belgium as the participating centres covered $77 \%$ of total sales in Belgium over the study period. A total of 114 patients with lymphoma or MM undergoing stem cell mobilization were included in the registry.

Success was defined as a total yield collected over the complete mobilization session of $2 \times 10^{6} \mathrm{CD} 34+$

Table 5 Number of administration days of plerixafor for patients with myeloma, lymphoma and the entire study population

\begin{tabular}{lccc}
\hline Number of administration days of plerixafor & MM $(\boldsymbol{n}=\mathbf{4 6 )}$ & NHL + HL $(\boldsymbol{n}=\mathbf{6 8})$ \\
\hline 1 & $23(50.0 \%)$ & $29(42.6 \%)$ & $52(45.6 \%)$ \\
2 & $17(37.0 \%)$ & $27(39.7 \%)$ & $44(38.6 \%)$ \\
3 & $6(13.0 \%)$ & $11(16.2 \%)$ & $17(14.9 \%)$ \\
13 & $0(0.0 \%)$ & $1(1.5 \%)$ & $1(0.9 \%)$ \\
\hline
\end{tabular}

Note: MM, multiple myeloma; NHL, non-Hodgkin's Iymphoma; HL, Hodgkin's Iymphoma. 
cells $/ \mathrm{kg}$ or more. Overall success rate of mobilization with plerixafor in the difficult to mobilize population included in this registry was $77 \%$. The success rate was higher in patients in a first mobilization attempt $(82 \%)$ as compared to patients having already undergone a previous mobilization attempt (63\%).

When looking at the information by disease type, success rate was higher in patients with MM than in lymphoma patients ( 84 vs $72 \%$ ), which corresponds to earlier observations in the registration phase III trials for plerixafor. ${ }^{13,14}$

Analysis of the relationship between pre-plerixafor CD34 + cell counts and the total yield collected per patient shows a relatively high success rate $(40 \%)$ in those patients with very low pre-plerixafor CD34+ cell counts (below 2 cells $/ \mu 1$ ). Interestingly, the cut-off value of 10 cells $/ \mu 1$ blood correlates with a $100 \%$ success rate with plerixafor.

In general, results observed in a real world context are often less positive then those observed in a wellcontrolled clinical trial context. Efficacy results reported for plerixafor in clinical trials are indeed somewhat better than those observed in our registry. This is not surprising as the population in our registry was a selected group meeting the reimbursement criteria for plerixafor in Belgium. These patients by definition can be classified as patients with mobilization difficulties.

In patients with known collection failure in a previous attempt, Hubel et al. ${ }^{19}$ reported a success rate of $73.8 \%$ in a median of two apheresis days based on data from the European Compassionate Use Program for plerixafor with better results in patients with MM (success rate $81.6 \%$ ) than in patients with NHL (success rate $64.8 \%$ ). For the Belgian patients included in this European Compassionate Use Program, a success rate of $64 \%$ in a mean of two apheresis sessions has been reported, ${ }^{20}$ which is in line with the observation in this registry in the group of patients with known mobilization failure $(63 \%)$.

Plerixafor use in a first mobilization attempt has been described by Russell et al. ${ }^{21}$ who has reported results of the European multicentre PREDICT trial in which plerixafor was used in first line in all mobilization attempts. Success rate was $96 \%$ in a median of 1 day of apheresis (range 1-3). By disease type, a $98 \%$ success rate was observed in patients with MM and $80 \%$ in patients with NHL. The mean fold increase of $\mathrm{CD} 34+$ cell counts after one dose of plerixafor was 2.6. Despite the fact that the population enrolled in the Belgian registry was restricted to difficult to mobilize patients (as defined by the reimbursement criteria in Belgium), the data observed in this registry are in line with the PREDICT trial. In the Belgian registry, the observed success rate of the first mobilization attempt was 88 and $76.5 \%$ in patients with MM or lymphoma, respectively. Mean fold increase of CD34 + cell count after one dose of plerixafor in the registry was 2.78 , which is very close to that observed in the PREDICT trial.

Data in patients with low pre-plerixafor CD34+ cell counts after 4 days of G-CSF have been published recently, based on a post hoc analysis of the double blind controlled phase III trials for plerixafor in MM and NHL. ${ }^{22,23}$ In these publications, failure rate in the placebo groups (patients mobilized with G-CSF alone) for patients with low CD34+ cell counts at Day 4 are high. In patients with $\mathrm{MM}$ with less than $15 \mathrm{CD} 34+$ cells/ $\mu$ after 4 days of G-CSF administration, total collection yield obtained in the G-CSF alone group was below the minimum target in $22 \%$ of the patients. ${ }^{23}$ It was below the minimum target in $5 \%$ of the patients mobilized with plerixafor and $\mathrm{G}-\mathrm{CSF}^{23}$ In this Belgian registry, for $12 \%$ of the MM patients a total yield below target was obtained after first line mobilization with plerixafor. Per inclusion criteria, these patients presented with less than $15 \mathrm{CD} 34+$ cells before plerixafor administration. In the post hoc analysis of the phase III trial in NHL, ${ }^{22}$ failure rate in the placebo group of patients with a CD34+ cell count below $15 \mathrm{CD} 34+$ cells/ $\mu 1$ after 4 days of GCSF administration was $59 \%$. The failure rate was $19 \%$ in the comparative group with low pre-apheresis $\mathrm{CD} 34+$ count mobilized with plerixafor and G$\mathrm{CSF}^{22}$ In the Belgian registry, $23.5 \%$ of the patients

Table 6 Total yield CD34+ cells collected in relation to pre-plerixafor CD34+ cell counts. Collection failure was defined as a collection yield below $2 \times 10^{6}$ CD34+ cells $/ \mathrm{kg}$. Collection success was defined as a collection yield above $2 \times 10^{6}$ CD34+ cells/kg

\begin{tabular}{lclr}
\hline $\begin{array}{l}\text { Pre-plerixafor CD34+ } \\
\text { cell counts (cells/ } \boldsymbol{\mu l})\end{array}$ & $\begin{array}{l}\text { Patients with collection } \\
\text { failure, } \boldsymbol{n}(\%)\end{array}$ & $\begin{array}{l}\text { Patients with collection } \\
\text { success, } \boldsymbol{n}(\%)\end{array}$ & Total number of patients, $\boldsymbol{n}(\%)$ \\
\hline$<2$ & $15(60.0 \%)$ & $10(40.0 \%)$ & $25(100 \%)$ \\
$2-5$ & $7(24.1 \%)$ & $22(75.8 \%)$ & $26(100 \%)$ \\
$5-10$ & $4(15.3 \%)$ & $22(84.6 \%)$ & $19(100 \%)$ \\
$10-15$ & $0(0 \%)$ & $19(100 \%)$ & $14(100 \%)$ \\
$>15$ & $0(0 \%)$ & $87(76.9 \%)$ & $113(100 \%)$ \\
\hline
\end{tabular}

Note:

*Information is missing for one patient. 
with lymphoma who received plerixafor with a baseline CD34+ count less than 15 cells $/ \mu 1 \mathrm{did}$ not collect the minimum of $2 \times 10^{6}$ cells $/ \mathrm{kg}$. In summary, failure rates with plerixafor mobilization in poor mobilizers in the Belgian registry compared to those observed in the post hoc analysis of the phase III trials are higher (12 vs $5 \%$ in MM, 23.5 vs $19 \%$ in lymphoma). This can partially be attributed to the fact that in the phase III trial no remobilization patients were included, while $27.2 \%$ of the patients in the registry had already experienced a previous mobilization attempt.

Analysis of the literature regarding cut-off values for $\mathrm{CD} 34+$ cell counts after at least 4 days of treatment with G-CSF indicates that cut-off values for pre-plerixafor CD34 + cell counts implemented in some centres in US and EU and defining a group of 'proven poor mobilizers' are close to those used in the Belgian reimbursement criteria. ${ }^{8,24-29}$ In addition to decision making based on pre-apheresis CD34+ cell counts, in many centres 'known poor mobilizers' (patients with previous mobilization failure, i.e. a collection yield of less than $2 \times 10^{6}$ cells $/ \mathrm{kg}$ ) are treated with plerixafor. Belgian reimbursement criteria also include these 'known poor mobilizers'.

One Serious Adverse Event (allergic reaction to plerixafor) was reported. Overall, plerixafor was well tolerated with adverse events (of mild or moderate intensity) reported in $6 \%$ of the patients. AEs were mainly gastrointestinal. Hypotension as adverse event was reported in two patients and in the patient who presented with allergic reaction. These data are in line with literature data.

\section{Conclusion}

The criteria for reimbursed use of plerixafor in Belgium are comparable with the strategies of use implemented in different countries and centres worldwide. Reported efficacy and safety information from the Belgian registry is in line with the published results of clinical studies in comparable patient populations.

\section{Acknowledgements}

The authors wish to thank S. Deferme, $\mathrm{PhD}$ (PharmaXL, Belgium) for his assistance in writing and publishing this manuscript. The authors acknowledge Sanofi for the financial support of the study.

\section{References}

1 Hosing C, Saliba RM, Ahlawat S, Korbling M, Kebriaei P, Alousi A, et al. Poor hematopoietic stem cell mobilizers: a single institution study of incidence and risk factors in patients with recurrent or relapsed lymphoma. Am J Hematol. 2009;84(6):335-7.

2 Lefrere F, Zohar S, Ghez D, Delarue R, Audat F, Suarez F, et al. The VAD chemotherapy regimen plus a G-CSF dose of $10 \mathrm{microg} / \mathrm{kg}$ is as effective and less toxic than high-dose cyclophosphamide plus a G-CSF dose of $5 \mathrm{microg} / \mathrm{kg}$ for progenitor cell mobilization: results from a monocentric study of 82 patients. Bone Marrow Transplant. 2006;37(8):725-9.

3 Mazumder A, Kaufman J, Niesvizky R, Lonial S, Vesole D, Jagannath S. Effect of lenalidomide therapy on mobilization of peripheral blood stem cells in previously untreated multiple myeloma patients. Leukemia. 2008;22(6):1280-1.

4 Micallef IN, Apostolidis J, Rohatiner AZ, Wiggins C, Crawley CR, Foran JM, et al. Factors which predict unsuccessful mobilisation of peripheral blood progenitor cells following GCSF alone in patients with non-Hodgkin's lymphoma. Hematol J. 2000;1(6):367-73.

5 Paripati H, Stewart AK, Cabou S, Dueck A, Zepeda VJ, Pirooz $\mathrm{N}$, et al. Compromised stem cell mobilization following induction therapy with lenalidomide in myeloma. Leukemia. 2008;22(6):1282-4.

6 Pavone V, Gaudio F, Guarini A, Perrone T, Zonno A, Curci P, et al. Mobilization of peripheral blood stem cells with high-dose cyclophosphamide or the DHAP regimen plus G-CSF in nonHodgkin's lymphoma. Bone Marrow Transplant. 2002;29(4):28590.

7 Popat U, Saliba R, Thandi R, Hosing C, Qazilbash M, Anderlini $\mathrm{P}$, et al. Impairment of filgrastim-induced stem cell mobilization after prior lenalidomide in patients with multiple myeloma. Biol Blood Marrow Transplant. 2009;15(6):718-23.

8 Pusic I, Jiang SY, Landua S, Uy GL, Rettig MP, Cashen AF, et al. Impact of mobilization and remobilization strategies on achieving sufficient stem cell yields for autologous transplantation. Biol Blood Marrow Transplant. 2008;14(9):1045-56.

9 Stiff P, Gingrich R, Luger S, Wyres MR, Brown RA, LeMaistre $\mathrm{CF}$, et al. A randomized phase 2 study of PBPC mobilization by stem cell factor and filgrastim in heavily pretreated patients with Hodgkin's disease or non-Hodgkin's lymphoma. Bone Marrow Transplant. 2000;26(5):471-81.

10 Sugrue MW, Williams K, Pollock BH, Khan S, Peracha S, Wingard JR, et al. Characterization and outcome of 'hard to mobilize' lymphoma patients undergoing autologous stem cell transplantation. Leuk Lymphoma. 2000;39(5-6):509-19.

11 Watts MJ, Ings SJ, Leverett D, MacMillan A, Devereux S, Goldstone AH, et al. ESHAP and G-CSF is a superior blood stem cell mobilizing regimen compared to cyclophosphamide $1.5 \mathrm{~g} \mathrm{~m}(-2)$ and G-CSF for pre-treated lymphoma patients: a matched pairs analysis of 78 patients. $\mathrm{Br} \mathrm{J}$ Cancer. 2000;82(2):278-82.

12 Dreger P, Kloss M, Petersen B, Haferlach T, Loffler H, Loeffler $\mathrm{M}$, et al. Autologous progenitor cell transplantation: prior exposure to stem cell-toxic drugs determines yield and engraftment of peripheral blood progenitor cell but not of bone marrow grafts. Blood. 1995;86(10):3970-8.

13 Dipersio JF, Micallef IN, Stiff PJ, Bolwell BJ, Maziarz RT, Jacobsen E, et al. Phase III prospective randomized doubleblind placebo-controlled trial of plerixafor plus granulocyte colony-stimulating factor compared with placebo plus granulocyte colony-stimulating factor for autologous stem-cell mobilization and transplantation for patients with nonHodgkin's lymphoma. J Clin Oncol. 2009;27(28):4767-73.

14 Dipersio JF, Stadtmauer EA, Nademanee A, Micallef IN, Stiff PJ, Kaufman JL, et al. Plerixafor and G-CSF versus placebo and G-CSF to mobilize hematopoietic stem cells for autologous stem cell transplantation in patients with multiple myeloma. Blood. 2009;113(23):5720-6.

15 Calandra G, McCarty J, McGuirk J, Tricot G, Crocker SA, Badel $\mathrm{K}$, et al. AMD3100 plus G-CSF can successfully mobilize CD34+ cells from non-Hodgkin's lymphoma, Hodgkin's disease and multiple myeloma patients previously failing mobilization with chemotherapy and/or cytokine treatment: compassionate use data. Bone Marrow Transplant. 2008;41(4):331-8

16 Micallef IN, Ho AD, Klein LM, Marulkar S, Gandhi PJ, Calandra $\mathrm{G}$, et al. Plerixafor (Mozobil) for stem cell mobilization in patients with multiple myeloma previously treated with lenalidomide. Bone Marrow Transplant. 2011;46(3):350-5.

17 Stiff P, Micallef I, McCarthy P, Magalhaes-Silverman M, Weisdorf D, Territo M, et al. Treatment with plerixafor in nonHodgkin's lymphoma and multiple myeloma patients to increase the number of peripheral blood stem cells when given a mobilizing regimen of G-CSF: implications for the heavily pretreated patient. Biol Blood Marrow Transplant. 2009;15(2):249-56.

18 Tricot G, Cottler-Fox MH, Calandra G. Safety and efficacy assessment of plerixafor in patients with multiple myeloma proven or predicted to be poor mobilizers, including assessment 
of tumor cell mobilization. Bone Marrow Transplant. 2010;45(1):63-8

19 Hubel K, Fresen MM, Apperley JF, Basak GW, Douglas KW, Gabriel IH, et al. European data on stem cell mobilization with plerixafor in non-Hodgkin's lymphoma, Hodgkin's lymphoma and multiple myeloma patients. A subgroup analysis of the European Consortium of stem cell mobilization. Bone Marrow Transplant. 2012;47(8):1046-50.

20 Selleslag D, Dierickx D, Breems DA, Huynh P, Van D, V, Meers S, et al. Plerixafor in poor stem cell mobilizers: the Belgian Compassionate Use Program. Acta Clin Belg. 2011;66 (3):200-4.

21 Russell N, Douglas K, Ho AD, Mohty M, Carlson K, Ossenkoppele GJ, et al. Plerixafor and granulocyte colonystimulating factor for first-line steady-state autologous peripheral blood stem cell mobilization in lymphoma and multiple myeloma: results of the prospective PREDICT trial. Haematologica. 2013;98(2):172-8.

22 Maziarz RT, Nademanee AP, Micallef IN, Stiff PJ, Calandra $\mathrm{G}$, Angell J, et al. Plerixafor plus granulocyte colony-stimulating factor improves the mobilization of hematopoietic stem cells in patients with non-Hodgkin lymphoma and low circulating peripheral blood CD34 + cells. Biol Blood Marrow Transplant. 2013;19(4):670-5.

23 Nademanee AP, Dipersio JF, Maziarz RT, Stadtmauer EA, Micallef IN, Stiff PJ, et al. Plerixafor plus granulocyte colonystimulating factor versus placebo plus granulocyte colonystimulating factor for mobilization of CD34 $(+)$ hematopoietic stem cells in patients with multiple myeloma and low peripheral blood CD34(+) cell count: results of a subset analysis of a randomized trial. Biol Blood Marrow Transplant. 2012;18(10): 1564-72.

24 Abhyankar S, DeJarnette S, Aljitawi O, Ganguly S, Merkel D, McGuirk J. A risk-based approach to optimize autologous hematopoietic stem cell (HSC) collection with the use of plerixafor. Bone Marrow Transplant. 2012;47(4):483-7.

25 Chen AI, Bains T, Murray S, Knight R, Shoop K, Bubalo J, et al. Clinical experience with a simple algorithm for plerixafor utilization in autologous stem cell mobilization. Bone Marrow Transplant. 2012;47(12):1526-9.

26 Li J, Hamilton E, Vaughn L, Graiser M, Renfroe H, Lechowicz MJ, et al. Effectiveness and cost analysis of 'just-in-time' salvage plerixafor administration in autologous transplant patients with poor stem cell mobilization kinetics. Transfusion. 2011;51(10):2175-82.

27 Micallef IN, Sinha S, Gastineau DA, Wolf R, Inwards DJ, Gertz MA, et al. Cost-effectiveness analysis of a risk-adapted algorithm of plerixafor use for autologous peripheral blood stem cell mobilization. Biol Blood Marrow Transplant. 2013;19(1):87-93

28 Olivieri A, Marchetti M, Lemoli R, Tarella C, Iacone A, Lanza $\mathrm{F}$, et al. Proposed definition of 'poor mobilizer' in lymphoma and multiple myeloma: an analytic hierarchy process by ad hoc working group Gruppo ItalianoTrapianto di Midollo Osseo. Bone Marrow Transplant. 2012;47(3):342-51.

29 To LB, Levesque JP, Herbert KE. How I treat patients who mobilize hematopoietic stem cells poorly. Blood. 2011;118(17): $4530-40$ 